\title{
層状基板における漏洩ラム波の伝搬特性と すだれ状トランスデューサの動作特性
}

\author{
非会員 藤田 剛* 正 員 戶田 耕司 ${ }^{*}$ \\ Propagation Characteristics of Leaky Lamb Waves in Layered Substrate and Operation \\ Performances of Interdigital Transducer \\ Takeshi Fujita*, Non-member, Kohji Toda*, Member
}

\begin{abstract}
Propagation characteristics of seven lowest modes of leaky Lamb waves in a layered substrate composed of a piezoelectric ceramic plate and an acrylic plate, under the condition of a liquid-solid boundary at the acrylic plate side, are described in the relationship with operation performances of an interdigital transducer (IDT) for underwater ultrasound. The IDT operates effectively for radiating or detecting via a mode conversion from the leaky Lamb wave to a longitudinal wave in a liquid. The incorporation of a layered substrate is useful for multiple-modes operations with higher transducer efficiencies, while retaining sufficient mechanical strength. It is noticeable that the cross points of the velocity curves of the leaky Lamb wave modes and the longitudinal wave modes in two kinds of thin plates for the layered substrate are unique for the transducer operations. The transducer operations are examined in the construction of a liquid delay line. The transducers designed for operating on the cross points of three modes are well explained in comparison between the calculated and experimental results.
\end{abstract}

キーワード：漏洩ラム波，伝搬特性，すだれ状トランスデューサ，液中超音波

Keywords: leaky Lamb wave, propagation characteristics, interdigital transducer, underwater ultrasound

\section{1. まえがき}

漏洩ラム波の伝搬問題は非破壊的材料評価の観点から大 きな関心を集めている(1) (4)。音波の伝搬媒体はほとんど の場合 , 金属などの非圧電体である。非圧電体への弾性波

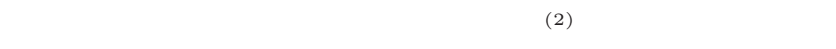
射による熱弾性効果が一般に用いられている(5)(6)。これら の研究は, 伝搬媒体としての基板材料の評価に主眼が注が れており，液中超音波用のトランスデューサとの関係から の議論は，ほとんどなされていない。液中超音波の使用は， 非破壞検査等の音響撮像 ${ }^{(8)}(9)$, 超音波診断 ${ }^{(10)(11)}$, 流量· 流速測定 ${ }^{(12)(13)}$ ，キャビテーションによる音響化学変化 ${ }^{(7)}$ 等の分野で盛んに研究がなされている。

液中超音波計測技術の骨幹として，トランスデューサの 設計は非常に重要である。異方性を有する圧電板における 漏洩ラム波の伝搬問題を基に，液中超音波用卜ランスデュー サの動作特性を明確にし，設計指針を得ることは有用と考

\footnotetext{
* 防衛大学校 電気情報学群 電気電子工学科

于 239-8686 横須賀市走水 1-10-20

Dept. of EE, National Defense Academy

1-10-20, Hashirimizu, Yokosuka 239-8686
}

えられる。液中超音波用トランスデューサには厚み振動モ一 ドを用いたバルク波タイプのものが一般的に使用されてい る。この場合, 超音波ビ一ムの液中への放射方向は基板面 に対して垂直方向で ${ }^{(10)(11)}$, 動作周波数は基板の寸法に制 限される。

一方，液体負荷の状態にある基板を伝搬する漏洩弾性波 は，液中への縦波超音波にモード変換される ${ }^{(14)}$ 。このよう な漏洩弾性波から液中縦波へのモ一ド变換は, 液中超音波 の斜め方向の放射に有効である。伝搬媒体が圧電性を有す る場合には，漏洩ラム波の励起・受波のためにすだれ状卜 ランスデューサ (IDT) の使用が有効と考えられる。圧電 磁器板単体での漏洩ラム波の伝搬を液中超音波用のトラン スデューサに用いる場合，有効に機能するモード数が少な く，しかも高周波化のためには基板の厚さが極めて薄くな り，機械的強度上の問題が存在する ${ }^{(15)}$ 。IDT の高機能な 動作を引き出すためには, 基板を伝搬する弾性波の伝搬特 性の本質的な理解及びラム波の多モード動作を効果的に実 現するための条件を把握する必要がある。

本論文では, 圧電磁器薄板とアクリル薄板からなる層状 基板での漏洩ラム波の伝搬特性の数值解析結果を用いて， 液中超音波用すだれ状トランスデューサの動作特性を明ら 
かにすることを主眼として研究した結果について述べてい る。アクリル板の使用は, 高周波動作での圧電薄板の機械 的強度を補強するために，高次モード動作を意図したこと による。圧電磁器薄板とアクリル薄板の層状基板における 固体・液体界面での 7 つの低次モードの漏洩ラム波の伝搬 特性とともに, 各ラム波モ一ドの分散曲線の交点近傍，並 びに 2 種類の縦波の分散曲線との交点近傍に IDT の動作特 性に優位性が認められる点が存在することを明らかにして いる。2つのモードが共存する領域では，モードの交叉も しくは反発により特異な動作特性の存在が考えられること から，電気機械結合係数又はモード 変換効率に極值が存在 することが期待される。本文では，弚れらの極值点近傍で の動作に着目すべきであることを示している。さらに，極 値点近傍での動作を確認するために，1枚の層状基板上に 2 組のIDT を用いた液体遅延線を構成し，実験によって検 討している。

速度分散曲線全体の理解の上に，極值点近傍での IDT の 動作に着目することにより，電気機械結合係数及びモード变 換効率が共に極大值を有する液中超音波用卜ランスデュー サ，あるいは電気機械結合係数が大きくモード変換効率が 極小を示す液相センサとして機能するトランスデューサの 作成に有効な情報を得ることが可能となる。ここでは $7 つ$ の低次モードを取り扱っているが，第 8 モード以上の高次 モードの伝搬特性は類似の傾向にある。実験に用いた液体 遅延線では，入力用 IDTから液中に放射された超音波ビー 么は，液体層を介して反射板によって反射された後，もう 1 組の IDT で遅延電気信号として出力される。この液体遅 延線を用いて，超音波ビームの放射方向と周波数の関係か ら，基板を伝搬する漏洩ラム波の位相速度を実験的に検証 している。

\section{2. 漏洩亏ム波の伝搬特性}

液体との界面を有するアクリル薄板と圧電磁器薄板との 層状基板において，漏洩ラム波の伝搬特性と IDT の動作 特性の関係を数值解析によって明らかにすることが本節で の基本である。漏洩ラム波の伝搬特性の解析には，圧電性 を有する基板材料での異方性とともに，液体との界面での 境界条件を考慮する必要がある。このため，Farnell の手

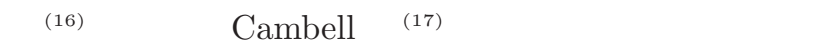
拡張し，層状基板における固体・固体及び固体・液体界面 での境界条件下で拡張し,数值代入法によって計算を行って いる。光のため，位相速度を複素数表示し，光の虚数成分 を漏洩波の減少定数と関係づけるとともに, 各界面での変 位, 応力及び電束密度の連続性が満足されることに留意し ている(18)。ここで用いたアクリル薄板は住友化学製テク ノロイで, 厚さは $125 \mu \mathrm{m}$ である。圧電磁器薄板は厚さが $218 \mu \mathrm{m}$ の TOKIN 製 NEPEC-6 で，分極軸は厚さ方向に ある。計算に必要な材料定数は文献 ${ }^{(19)}$ に示されている。

图 1 は計算に用いた座標系と 2 組の IDT を用いた液体 遅延線の構成を表している。圧電磁器薄板とアクリルとの

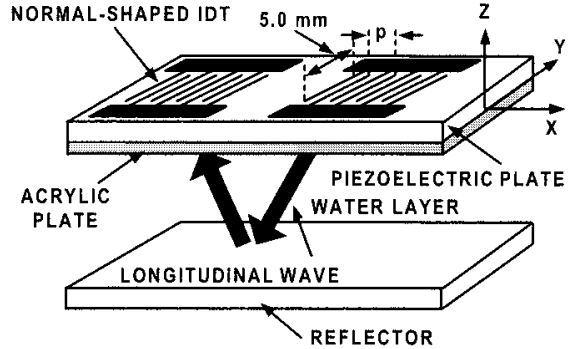

図 1 層状基板上に 2 組の IDT を有する漏洩 ラム波デバイスと液体遅延線の構成

Fig. 1. Schematic of leaky Lamb wave device with two IDTs on layered substrate and construction of liquid delay line.

接触面上に原点を配置して, IDT の電極指と垂直かつ基板 面と平行な方向を X 軸, 基板と垂直な方向を Z 軸としてい る。圧電磁器薄板の片面が空気, 反対側の面がアクリルと接 しており，アクリルのもう一方の面は水と接している。圧 電磁器薄板の空気側の面上に送受 2 組の IDT が設けられ ている。層状基板と平行に水の層を介した状態で液中超音 波の反射板が配置されており，光の離間距離は可変である。 RF 発振器からの電気信号が入力用 IDT に印加されると， 層状基板に対し水中へ斜め方向に縦波超音波が放射される。 この超音波は層状基板と平行に配置した真鍮板によって反 射され，もう一方の IDT で遅延電気信号として検出され る。ここで, 基板面からの超音波の放射角度は次式を満足 する(20)。

$$
\theta_{W}=\sin ^{-1} \frac{v_{W}}{v}, \ldots \ldots \ldots \ldots \ldots \ldots \ldots \ldots
$$

ここで, $\theta_{W}, v_{W}, v$ は基板の垂線からの液中超音波の放 射角度，液中縦波及び漏洩亏公波の位相速度である。

図 2(a) には，層状基板を伝搬する 7 つ低次モードの 漏洩ラム波の位相速度が, 周波数 $f$ と圧電磁器薄板の厚さ $d$ の積の関数の形で示されている。この場合, 圧電磁器薄 板とアクリル薄板との厚さの比 $r$ は 0.573 であり，実験と の整合性を計った值である。ここでの圧電磁器薄板の電気 的境界条件は, 空気側が短絡 (short)，アクリル側は開放 (open) 状態である。図中の数字は各モードの通し 番号であ る。 $\mathrm{L}_{\mathrm{p}}$ 及び $\mathrm{L}_{\mathrm{a}}$ は, 層状基板の厚さが限りなく 0 に近い場 合での，圧電磁器薄板単体及びアクリル板単体中での緃波 速度の分散曲線 (実線) である。

図 2(b) は圧電磁器薄板単体を伝搬する5つの低次モ一 ド漏洩ラム波の位相速度の $f d$ 依存性を示しており，層状 基板での結果と比較するために, 同じ $f d$ 值の範囲での結 果である。図 (a) には各漏洩ラム波モードでの交点部分が 存在するが , 図 (b) には認められない。 $\mathrm{L}_{\mathrm{p}}$ あるいは $\mathrm{L}_{\mathrm{a}}$ の ラインと各漏洩波モードの交点は両図においてともに認め られるが，交点の数は層状の場合に 2 倍以上となる。

図 2 (a) における第 6 と第 7 モードの速度分散曲線の交 点近傍でのモ一ドの場合には，互いの位相速度が交叉する。 漏洩ラム波のモードの交叉もしくは反発の判断は, 複素数 


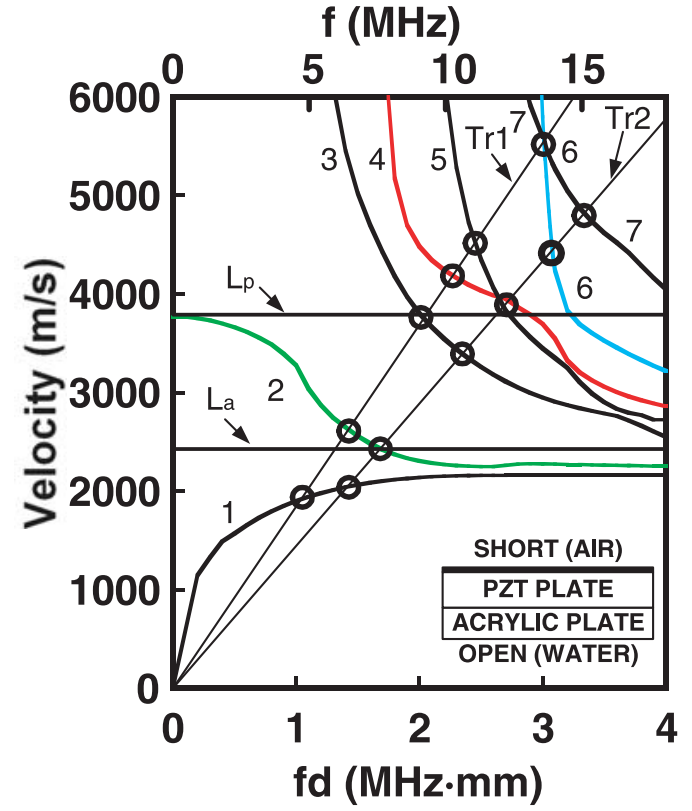

(a)

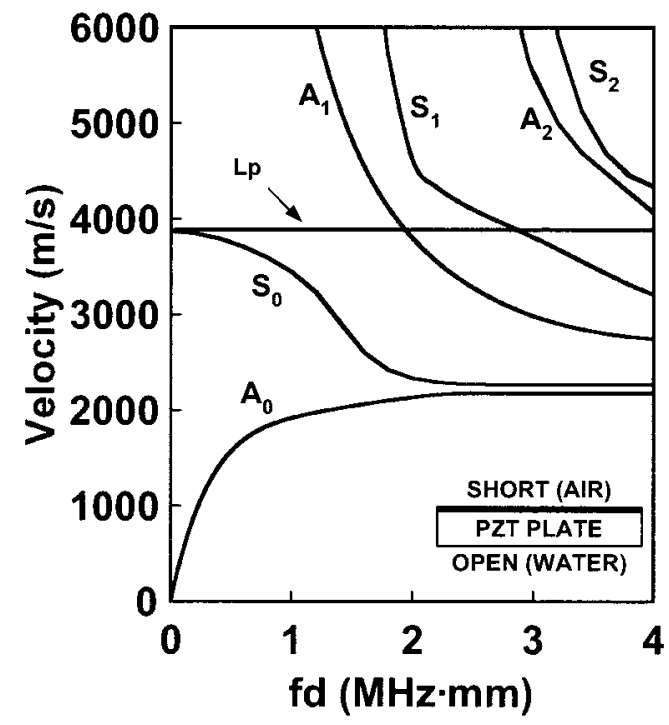

(b)

図 2 漏洩ラム波モードの位相速度の $f d$ 依存性 (電気的境界条件 : short/open; ○印は実験值，

(a)：層状基板，(b)：圧電磁器板単体)

Fig. 2. Velocity dispersion curves of leaky Lamb wave modes as function of $f d$ under electrically shorted/opened condition; filled circles are experimental data, (a) for layered substrate and (b) for only piezoelectric substrate.

で表される各モードの位相速度の実部及び虚部の連続性 を考慮することにより可能である。この場合，実部及び虚 部共に近い值を有しているため, 単純に速度の連続性から モードの連続性を判断することが困難である。このような 場合の判別のためには, 基板中の変位分布の連続性が有効 である。図 3 は第 6 モードと第 7 モードの $f d$ 值が 3.01 と $3.02 \mathrm{MHz} \cdot \mathrm{mm}$ の場合の Z 方向の変位分布の計算結果であ る。縦軸は, 圧電磁器薄板とアクリル板の境界面を原点と

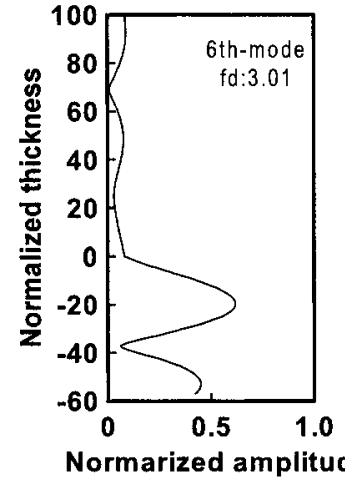

(a)

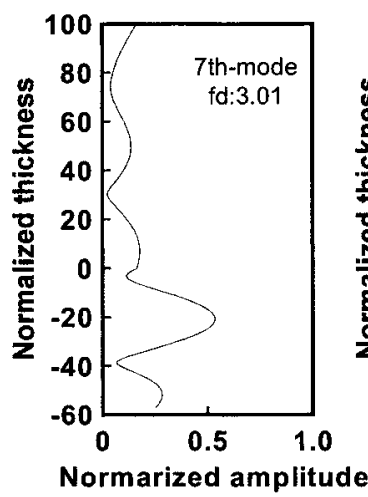

(c)

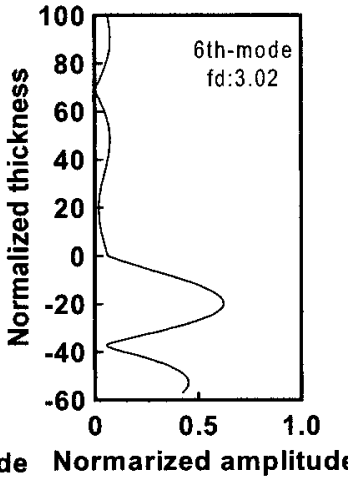

(b)

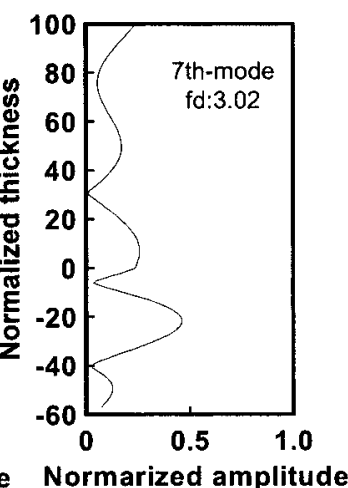

(d)
图 3 第 6,7 モードの変位分布の計算結果 ( $f d: 3.01,3.02 \mathrm{MHz} \cdot \mathrm{mm})$

Fig. 3. Calculated mechanical displacements of 6th and 7th modes for two $f d$ values of 3.01 and $3.02 \mathrm{MHz} \cdot \mathrm{mm}$

して, 圧電磁器薄板の厚さを 100 として規格化されている。 横軸は, 変位の最大值で規格化された变位振幅を表してい る。第 6 モードでは節の数が 3 箇, 第 7 モードでは 4 箇存 在し, 変位分布の連続性と矛盾しないことが分かり, $f d$ 值 が 3.01 と $3.02 \mathrm{MHz} \cdot \mathrm{mm}$ の間で，2つのモードが交叉する と判断できる。更に，この変位分布の結果は, アクリル板 側での弾性振動変位の局在を示すものであり，液中への放 射効率の向上に有効であることを示唆している。このよう な振動変位の偏つた分布は, 圧電磁器薄板単体での対称 $(\mathrm{S})$ モードあるいは反対称 $(\mathrm{A})$ モードと比べて複雑である。

図 4 は, 圧電磁器薄板の空気側が IDT(open 及び short), アクリル側の電気的境界条件が開放 (open) の場合の電気 機械結合係数 $k^{2} の f d$ 依存性の計算結果であり，次式を基 にして導かれている ${ }^{(18)}$ 。

$$
k^{2}=\frac{2\left|v_{o}-v_{s}\right|}{v_{o}},
$$

ここでの $v_{o}, v_{s}$ は, 圧電磁器薄板の空気側の電気的境界条 件が開放 (open) あるいは短絡 (short) 状態で, アクリル との接触面が開放 (open) 状態での漏洩ラム波の位相速度 である。図中の・印は各ラム波モード，縦波速度の速度曲 線の交点付近に存在する極大あるいは極小值を示したもの である。ここで, $3.2 \mathrm{MHz} \cdot \mathrm{mm}$ 近傍での・印は，第 3，4， 


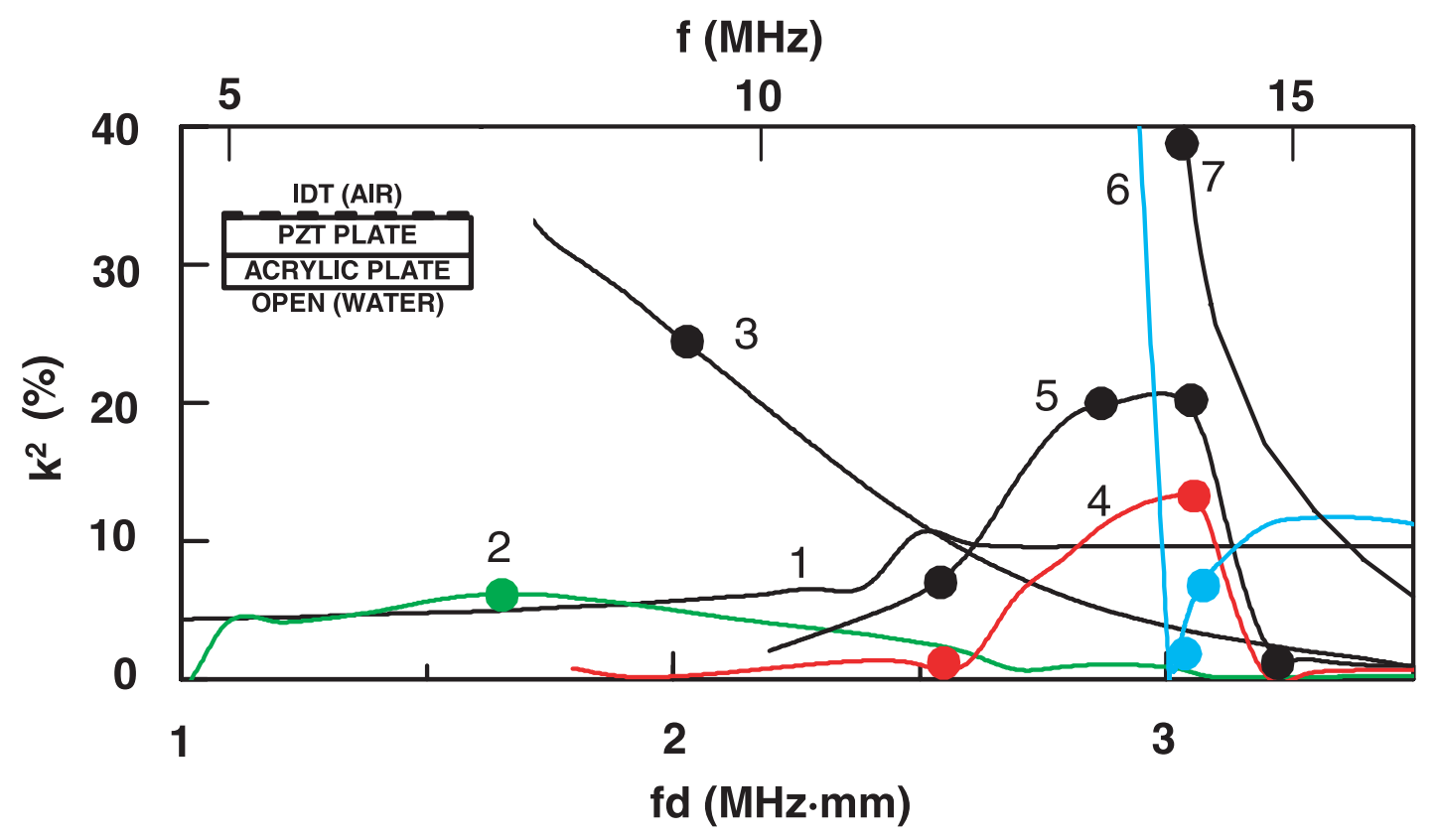

図 4 電気機械結合係数 $k^{2} の f d$ 依存性 (電気的境界条件 : IDT/open)

Fig. 4. Calculated electromechanical coupling constant $k^{2}$ as function of $f d$, under IDT/opened condition.

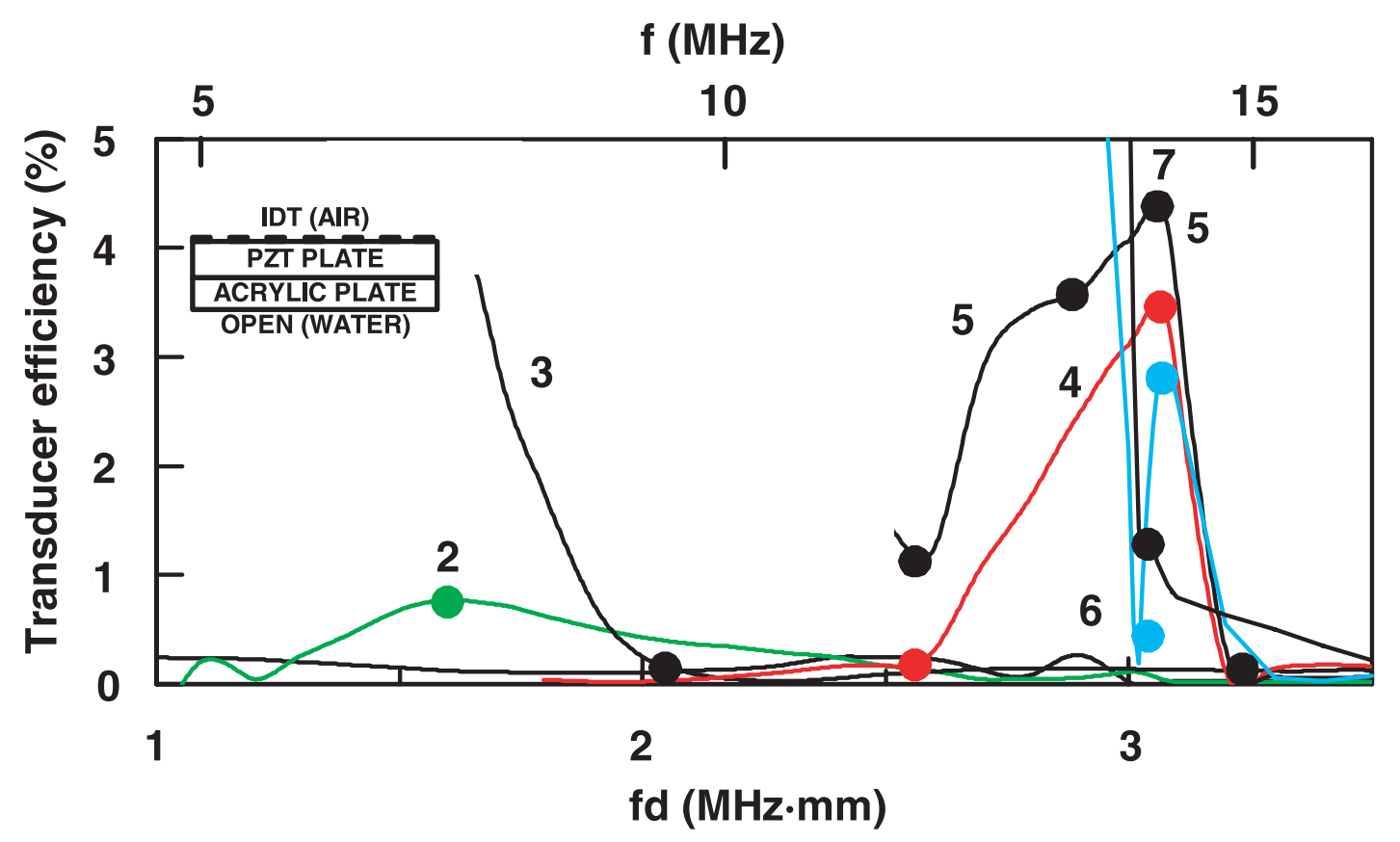

図 5 実効変換効率 $\eta$ の $f d$ 依存性の計算結果 (電気的境界条件 : IDT/open)

Fig. 5. Calculated transducer efficiency $\eta$ as function of $f d$, under IDT/opened condition.

5 の3つのモドが重複する部分であるため1つの・印で 表示されている。第 4,5 モードの $3.1 \mathrm{MHz} \cdot \mathrm{mm}$ 付近には モード反発により生じた極大点が存在する。これらの極大 点での $k^{2}$ 值は大きく, SAW デバイスの基板として一般的 に用いられる $128^{\circ} Y X \mathrm{LiNbO}_{3}$ の $k^{2}$ 值が自由境界面で約 $5.5 \%{ }^{(21)}$ であることと比較すると，ここでの值は評価し得 る値である。圧電磁器板単体の場合における $\mathrm{L}_{\mathrm{p}}$ との交点 での $\mathrm{A}_{1}$ モードの $k^{2}$ 值は約 $20 \%, \mathrm{~S}_{1}$ モードは約 $12 \%$ であ
り，圧電磁器単体基板に匹敵する効率値である。

漏洩ラム波は層状基板を伝搬する間に, 水中縦波へとモ一 ド変換され, 弚のモード変換効率 $C$ は次式によって定義さ れる。

$$
C=1-\exp \frac{4 \pi \operatorname{Im}(v)}{\operatorname{Re}(v)}
$$

図 5 はトランスデューサの実効変換効率 $\eta$ の $f d$ 依存性の 計算結果で，電気的境界条件は図 4 の場合と同樣に, IDT 
は空気側，アクリル側は開放状態の場合である。ここでの $\eta$ は, $k^{2}$ 值と $C$ 值の積で定義され, IDT の液中超音波用 トランスデューサとしての評価の目安を与えるものである。 図中の・印は図 4 の場合と同樣に，速度分散曲線上の交点 近傍に $\eta$ の極大あるいは極小值が存在することが認められ る。ここで, $k^{2}$ 值に極值がなく $\eta$ 值が極值を取るのは, $C$ 值が極値であることを意味する。图 4 での第 3 モードの・ 印に対応する $k^{2}$ 值は極值を取らないものの, $C$ 值は零に近 く，結果として $\eta$ 值は極小值を取ることが図 5 からも明ら かである。このような動作点を選択することによって，SH 波を用いた液相センサと同樣の動作が可能である。

\section{IDT の動作特性の実験的検証}

実験に用意した IDT の電極周期長 $p$ は , $400,320 \mu \mathrm{m}$ の 2 種類で，本論文中では光れ光れ $\operatorname{Tr} 1 ， \operatorname{Tr} 2$ と呼称される。 電極指の重なり幅 $\mathrm{w} は 5.0 \mathrm{~mm}$ ，対数は 10 対である。動作 の確認には，図 1で示した液体遅延線の構成において，基 板と超音波の反射板との離間距離を任意に変えられるよう に配置し，挿入損失の周波数依存性の測定によって検討し ている。ここで，液中超音波の放射角度は式 (1)の関係に より，漏洩ラム波の位相速度に依存し，基板と反射板との 離間距離に応じて出力が最大となる放射角度が決まる。実 験に用いた液体遅延線では，入力用 IDTから液中に放射さ れた超音波ビームは，液体層を介して反射板によって反射 された後，もう1組の IDT で遅延電気信号として出力さ れる。IDTへの印加電気信号の周波数を変化させることに よって動作モードの選択が可能である。基板から斜め方向 への超音波ビームの放射角度は，漏洩ラム波の位相速度と 液中超音波の速度の比で決まり，印加周波数によって制御 される。このことは，超音波ビームの放射方向と周波数の 関係を実験的に調べることによって，基板を伝搬する漏洩 ラム波の位相速度を推定できることを意味している。図 6 は，Tr-1 を用いて液体遅延線を構成し，第 6 モ一ドと第 7 モードの交点に対応する周波数 $14.0 \mathrm{MHz}$ の RF パルスを 入力信号とした場合に，出力が最大となるように離間距離 を調整することによって得られた時間応答特性の測定結果 である。IDT と反射板との離間距離が $8.9 \mathrm{~mm}$ で，式 (1) より液中超音波の放射角度が 15.6 度であることから，液中 超音波の伝搬経路長は $18.5 \mathrm{~mm}$ となる。この值は，図 6 で の水中超音波の伝搬遅延時間と水中での縦波速度から求め た伝搬経路長 $18.4 \mathrm{~mm}$ とよく一致する。この結果からの送 受の IDT の離間距離は $5.0 \mathrm{~mm}$ で，2つの電極パターンの IDT の中心間距離 $6.0 \mathrm{~mm}$ よりも少し 短い值である。この ことは, モード変換効率 $C$ が 1 ではないために, 液中超音 波の実際の放射位置が IDT の中心部から少しシフトしてい ることによるものである。

図 2(a) 中の直線 Tr-1 及び Tr-2 は, 本研究で用意した 2 種類のトランスデューサの動作直線を表し， $v=p f$ の 関係を満足している。ここで直線の傾き $p$ は, IDT の電極 周期長に相当する。IDT の有効な動作は，この動作直線と

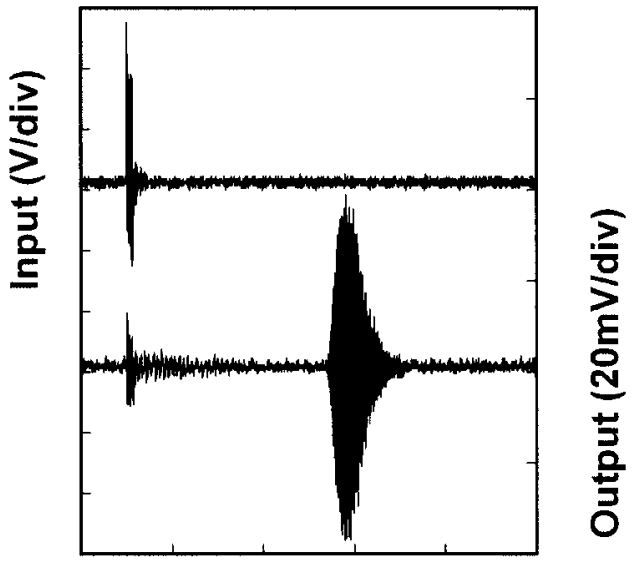

Time ( $5 \mu \mathrm{s} / \mathrm{div})$

図 6 液体遅延線における $\mathrm{RF}$ パルスの 時間応答特性の測定結果

Fig. 6. Observed input and output signals in case of $\operatorname{Tr} 1$ for 7 th mode at carrier frequency of 14.0 $\mathrm{MHz}$.

漏洩ラム波の速度分散曲線との交点近傍において可能であ る。○印で示した実験データは, 離間距離をパラメータと して液体遅延線の挿入損失の測定から得られた中心周波数 と IDT の電極周期長の積から求めた速度である。2 種類の IDT ( Tr1 と Tr2) に対応する動作直線と漏洩ラム波の各 モードの速度分散曲線の交点では, 数值計算結果と良く一 致している。ここで着目すべきことは，IDT の動作直線が， 複数個の速度分散曲線と交点を結ぶことであり，周波数の 選択により，多モードでの動作が可能であることである。

図 7 には, $f d$ 值が $3.0 \mathrm{MHz} \cdot \mathrm{mm}$ 近傍での第 6 モードと 第 7 モードの分散曲線，並びに IDT ( Tr1) の動作直線が 拡大した形で示されている。図中の $2 つ$ つム波モードの 交点付近でトランスデューサを動作させた場合には，図 5 からも明らかなように，第6モードは極小値を取り，第 7 モードが支配的である。

基板と超音波の反射板との離間距離を変化させることに より，この動作点近傍での挿入損失の周波数特性の測定結 果が図 8 に示されている。第7モードでの反射遅延信号が 最大となる中心周波数では, 第 6 モ一ドでの $k^{2}$ 值は極小值 を取り，無視できるレベルであるため，実質的に単1モー ドでの液中超音波トランスデューサとして機能している。 ここで，基板に対する液中超音波の放射角度は，式 (1)よ り漏洩ラム波の位相速度に依存する。速度分散性の大きい 場合には, 動作周波数の少しの変化により液中超音波の放 射もしくは受波角度を大きく变化することができる。図 8 での周波数領域では，図 2(a) からも明らかなように，帯域 内で速度分散性を有効に利用することが可能である。この ことは離間距離の変化を周波数変化によって追随しうると いう利点につながる。以上の点からも非常に有効な動作点 であると考えられる。第 6 と第 7 のつのモードには，こ の動作点よりも低周波側で, $k^{2}, \eta$ の大きい領域が存在す 


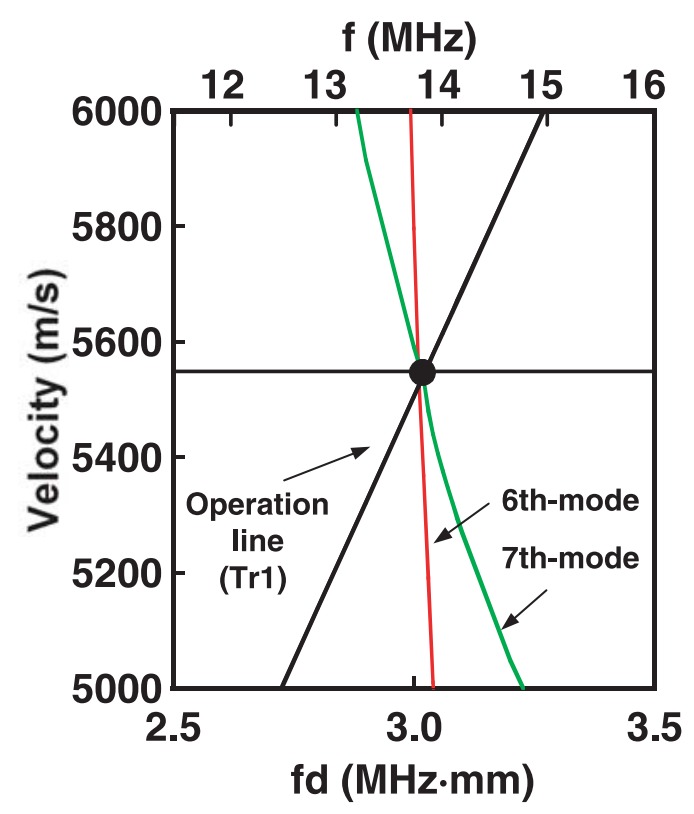

図 7 層状基板における第 6 , 第 7 モードの交点 近傍での速度分散曲線 (電気的境界条件 : short/open ; ○印は動作点に対応)

Fig. 7. Velocity dispersion curves of 6th and 7th modes of leaky Lamb wave in layered substrate around crossing point, under electrically shorted/opened condition; filled circles correspond to respective operation points.

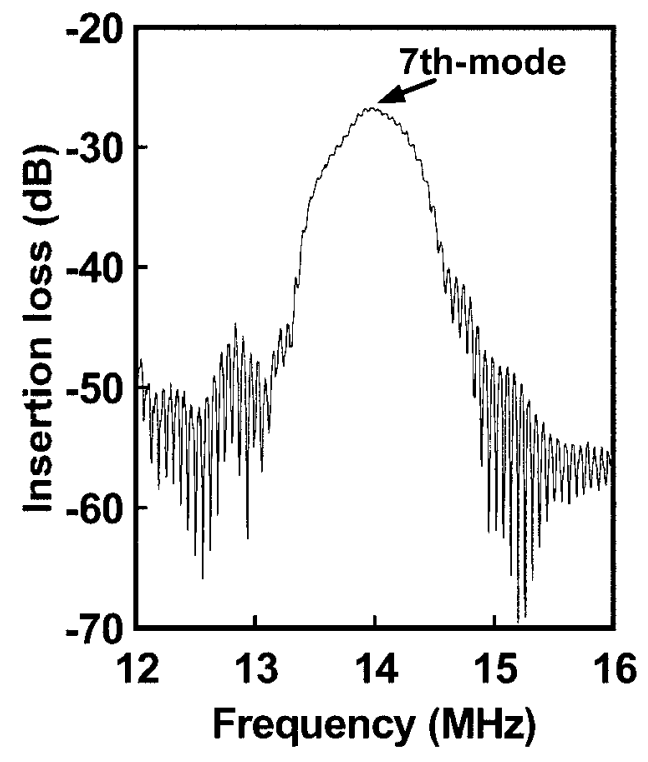

図 8 液体遅延線の挿入損失の周波数特性の 測定結果

Fig. 8. Measured frequency dependences of insertion loss of liquid delay line.

ることが図 4 , 図 5 から明らかである。この領域での液体 遅延線としての動作では，2つのモードの中心周波数が近 接し，干渉等の影響を受け易いという問題点が生ずる。

図 9 は第 2 モードとアクリル中の縦波速度 $\left(\mathrm{L}_{\mathrm{a}}\right)$ との交 点付近を IDT ( Tr2) の動作直線を含めて表している。こ

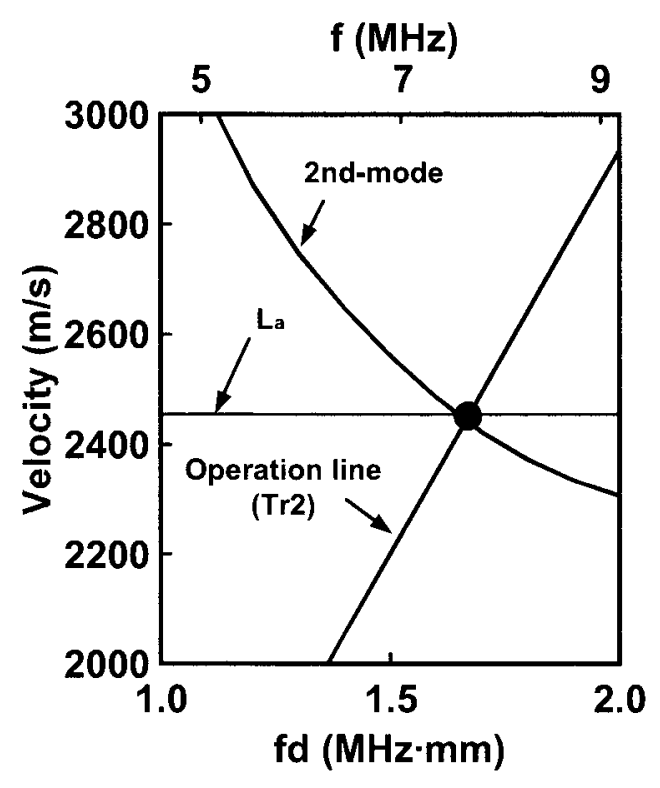

図 9 層状基板での第 2 モード漏洩ラム波と アクリル板単体での縦波の交点付近の速度 分散曲線 (電気的境界条件 : short/open; ○印は動作点に対応)

Fig. 9. Velocity dispersion curves of 2nd mode of leaky Lamb wave in layered substrate and longitudinal wave in only acrylic plate around crossing point, under electrically shorted/opened condition; filled circle is operation point.

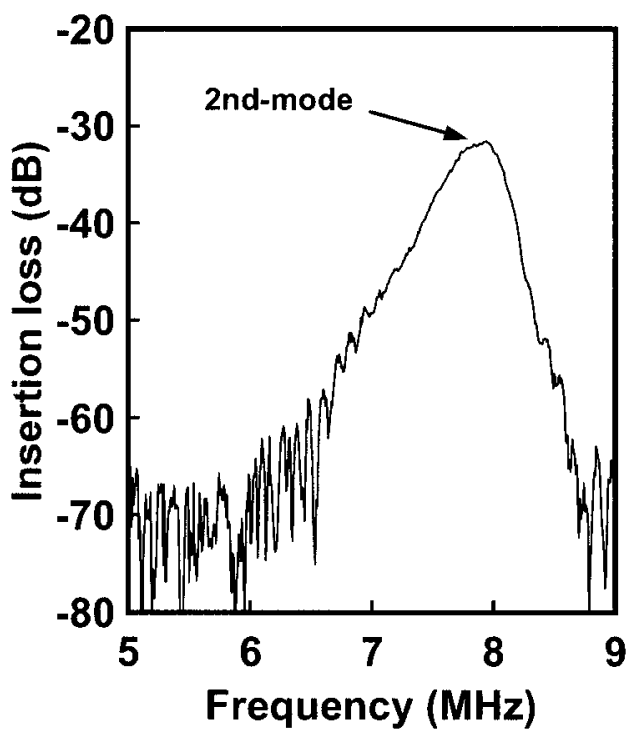

図 10 液体遅延線の挿入損失の周波数特性の 測定結果 (図 9 の動作ポイントに対応)

Fig. 10. Measured frequency dependence of insertion loss of liquid delay line, corresponding to operation point in Fig. 9.

こでの交点近傍において $k^{2}$ 值及び $C$ 值はともに極大值を 持つため, $\eta$ 值は極大となる。図 10 は, 第 2 モードとアク リル中の縦波速度 $\left(\mathrm{L}_{\mathrm{a}}\right)$ との交点近傍での動作において, 液 体遅延線の挿入損失が最小となるように離間距離を設定し た場合の，挿入損失の周波数依存性の測定結果である。こ 


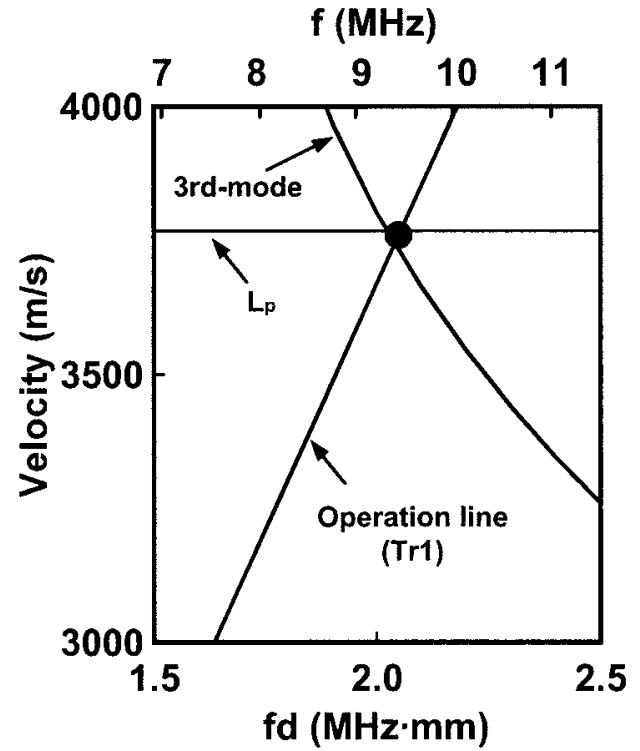

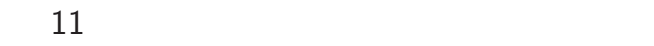
圧電磁器板単体中での縦波の交点近傍での 速度分散曲線 (電気的境界条件 : short/open)

Fig. 11. Velocity dispersion curves of 3rd mode of leaky Lamb wave in layered substrate and longitudinal wave in only piezoelectric ceramic plate around crossing point, under electrically shorted/opened condition

こでの中心周波数での挿入損失は約 $30 \mathrm{~dB}$ である。この值 は液体遅延線の構成，超音波非破壊検査のための卜ランス デューサとして十分に機能するレベルである。

つぎに電気機械結合係数が大きく，モード変換効率が非 常に小さい動作点の存在について述べる。図 11 は第3モ一 ドの速度分散曲線と圧電磁器薄板の縦波速度 $\left(\mathrm{L}_{\mathrm{p}}\right)$ 及び IDT （Tr1）の動作直線の交点近傍の特性を示している。この交 点に対応する $f d$ 值が $2.0 \mathrm{MHz} \cdot \mathrm{mm}$ 近傍で, 第 3 モードの $C$ 値がほぼ零であることから， $\eta$ 值が零に近いことが図 5 からも明らかである。水を負荷しない場合でのデバイスの 挿入損失は約 $19 \mathrm{~dB}$ であり，水を負荷した状態では，1dB 未満の変化に抑えられることが実験によって確認された。 このような液体負荷状態で，液中への縦波超音波の漏洩が 非常に少ないことは，SH 波を用いた負荷液体の材料物性の 評価のためのデバイスと同樣な構成が可能である。SH 波に 比べて振動変位が 2 方向，すなわち伝搬方向と基板面と垂 直方向に存在するために，SH 波を用いたセンサと競合ある いは補間する形で, 高感度での動作が期待できる ${ }^{(22) \sim(24) 。 ~}$

\section{4. むすび}

低次側の 7 つの漏洩ラム波モードで動作するすだれ状卜 ランスデューサの動作特性を，層状構造基板における漏洩 ラム波の伝搬特性との関係において, 数值解析と実験の両 面から検討を行った結果について述べた。圧電磁器薄板と アクリル板の層状基板を伝搬する漏洩ラム波の伝搬特性か ら，漏洩ラム波の速度曲線の各ラム波モード間の交点並び
に 2 層を構成する各基板単体での縦波速度との交点の近傍 で, IDTの電気機械結合係数とモード変換効率の積の形を 取る実効変換効率は，極大あるいは極小值を取ることが明 らかになった。このような速度分散曲線上の極值点での動 作に着目することは, IDT を漏洩ラム波トランスデューサ として液中超音波用，あるいは負荷液体の物性評価のため のデバイスの構成に有効な情報を与えるものである。ここ での計算結果を基にして , 層状基板に 2 組の IDT を有する デバイスを構成し，液体遅延線としての動作特性の測定か ら，数值計算と実験との良い一致が確認された。これらの 結果は，層状構造基板での多モード動作を活用する漏洩ラ 么波用 IDT を構成する際に，有効な動作点の選択に有用な 情報として考えられるものである。

(平成 15 年 2 月 18 日受付，平成 15 年 12 月 12 日再受付)

文献

(1) M. Deschamps and O. Poncelent: "Transient Lamb waves: Comparsion between theory and experiment," J. Acoust. Soc. Am., Vol.107, No.6, pp.3120-3129 (2000-6)

( 2 ) O.I. Lobkis, D.E. Chimenti, and H. Zhang: "In-plane property characterization in composite plates," J. Acoust. Soc. Am. Vol.107, No.4, pp.1852-1858 (2000-4)

( 3 ) D.E. Chimenti and R.W. Martin: "Non destructive evaluation of composite laminates by leaky Lamb waves," Ultrasonics, Vol.29, No.1, pp.13-21 (1991-1)

(4) A.K. Mal, P.C. Xu, and Y. Bar-Cohen: "Leaky Lamb waves for the ultrasonic nondestructive evaluation of adhesive bond," J. Eng. Mater. Technol. Trans. ASME, Vol.112, No.3, pp.255-259 (1990-7)

( 5 ) A. Cheng, T.W. Murray, and J.D. Achenbach: "Simlation of laser-generated ultrasonic wave in layered plates," J. Acoust. Soc. Am., Vol.110, No.2, pp.848-855 (2001-8)

( 6 ) S.J. Davis, C. Edwards, G.S. Taylor, and S.B. Palmer: "Laser-generated ultrasound: its properties, mechanism, and multifarious applications," J. Phys. D., Vol.26, pp.329-348 (1993)

( 7 ) S. Umemura, K. Kawabata, and K. Sasaki: "In Vitro and In Vivo enhancement of sonodynamically active cavitation by second-harmonic superimposition," J. Acoust. Soc. Am., Vol.101, No.1, pp.569-577 (1997-1)

( 8 ) K. Kim, H. Fukuhara, and H. Yamawaki: "Ultrasonic imaging of welded metals using simplified ultrasonic computerized tomography," Jpn. J. Appl. Phys., Vol.41, No.1, pp.374-378 (2002-1)

( 9 ) W.F. Walker: "C- and D-Weighted Ultrasonic Imaging Using the Translating Apertures Algorithm," IEEE Trans. Ultrason. Ferroelect. Freq. Contr., Vol.48, No.2, pp.452-461 (2001-3)

(10) T. Taxt and G.V. Frolova: "Noise robust one-dimensional blind deconvolution of medical ultrasound images," IEEE Trans. Ultrason. Ferroelect. Freq. Contr., Vol.46, No.2, pp.291-299 (1999-3)

(11) S. Saitoh, T. Takeuchi, T. Kobayashi, K. Harada, S. Shimanuki, and Y. Yamashita: "An improved phased array ultrasonic probe using $0.91 \mathrm{~Pb}\left(\mathrm{Zn}_{1 / 3} \mathrm{Nb}_{2 / 3}\right) \mathrm{O}_{3}-0.09 \mathrm{PbTiO}_{3}$ single crystal," Jpn. J. Appl. Phys., Vol.38, 1, No.5B, pp.3380-3384 (1999-5)

(12) M. Calzolai, L. Capineri, A. Fort, L. Masatti, S. Rocchi, and M. Scabia: "A 3-D PW Ultrasonic Doppler Flowmeter: Theory and Experimental Characterization," IEEE Trans. Ultrason. Ferroelect. Freq. Contr., Vol.46, No.1, pp.108-113 (1999-1)

(13) K. Kobayashi, T. Moriizumi, and K. Toda :"Longitudinal acoustic wave radiated from an arched interdigital transducer," J. Appl. Phys., Vol.52, No.8, pp.5386-5388 (1981)

(14) K. Toda and Y. Murata: "Acoustic focusing device with 
an interdigital transducer," J. Acoust. Soc. Am., Vol.62, pp.1033-1035 (1977)

(15) T. Fujita and K. Toda : "Operation performance of a liquid delay line oscillator using multi-mode leaky Lamb wave transducers," IEICE Trans., Vol.J85-C, No.5, pp.348-355 (2002-5) (in Japanese)

藤田 剛・戶田耕司 : “多モード漏洩ラム波すだれ状トランスデュー サを用いた液体遅延線発振器の動作特性”, 信学論 (C), J85-C, 5 , pp.348-355 (2002-5)

(16) G.W. Farnell: "Symmetry considerations for elastic layer modes propagating in anisotropic piezoelectric crystals," IEEE Trans. Sonics \& Ultrason., Vol.SU-17, No.4, pp.229238 (1970)

(17) J.J. Campbell and W.R. Jones: "A method for elastic layer modes propagating in anisotropic piezoelectric crystals," IEEE Trans. Sonics \& Ultrason., Vol.SU-15, No.4, pp.209-217 (1968)

(18) K. Toda and K. Ibuki : "Analysis of performance of leaky Lamb wave transducer operating at liquid-solid interface," Ferroelectrics, Vol.73, pp.419-430 (1987)

(19) Tokin Product catalogue (piezoelectric ceramics)

(20) K. Toda: "An acoustic focusing device with an interdigital transducer on a thin piezoelectric plate," Proc. IEEE, Vol.67, No.8, pp.1173-1174 (1979)

(21) 日本学術振興会弾性波素子技術第 150 委員会編：弾性波素子技術 ハンドブック, pp.160, オーム社 (1991)

( 22 ) F. Bender, R. Dahint, and F. Josse: "Acoustic wave-base sensors using mode conversion in periodic gratings," IEEE Trans. Ultrason. Ferroelect. Freq. Contr., Vol.46, No.6, pp.1497-1503 (1999-11)

(23) F. Josse and Z. Shana: "Effects of liquid relaxation time on SH surface waves liquid sensors," J. Acoust. Soc. Am. Vol.85, pp.1556-1559 (1989)

(24) M. Inoue, K. Yoshino, H. Moritake, and K. Toda: "Evaluation of nematic liquid-crystal director-orientation using shear

horizontal wave propagation," J. Appl. Phys., Vol.91, No.5, pp.2798-2802 (2002-3)

藤 田

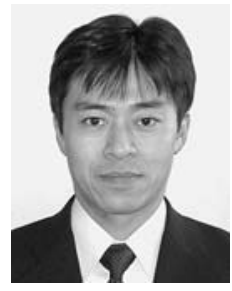

戸田 耕

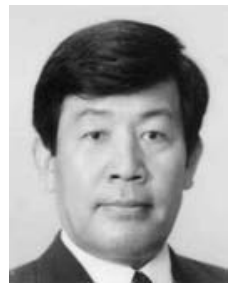

(正員) 1964 年防衛大学校 (電気工学専門) 卒 業。1969 年京都大学大学院工学研究科修士課程 電気系専攻修了。同年 4 月防衛大学校電気工学教 室助手。1986 年 4 月同教授。1973 年 9 月から 1 年間 Stanford 大学電気工学科客員助教授。工学 博士。表面波デバイス，強誘電体材料，音響撮像， センサなどの研究に従事。1972 年電子情報通信 学会米沢賞, 1985 年科学技術庁長官賞受賞。電 気学会, 応用物理学会, 日本音響学会会員。米国音響学会フェロー。 米国 Sigma Xi 会員。 